\title{
One-Pot Three Components Synthesis of 2,4,5-Triaryl-Imidazoles Catalyzed by Caro's Acid-Silica Gel Under Solvent-Free Condition
}

\author{
Majid Momahed Heravi, Narges Karimi*, Samira Pooremami
}

\section{ART I C L E I N F O}

Received: 16 December 2018

Revised: 29 December 2018

Accepted: 1 January 2019

Available online: 6 January 2019

\section{K E Y W O R D S}

MCR

Benzyl

Aldehydes

Ammonium acetate

Caro's acid-silica gel

\section{A B S T R A C T}

We introduced a very simple, one-pot three component procedure for preparation of 2,4,5-triaryl-imidazoles from the reaction of benzyl, aldehydes and ammonium acetate, as ammonia source, catalyzed by Caro's acid-silica gel under Solvent -free condition.

\section{GRA P H I C AL ABSTRACT}

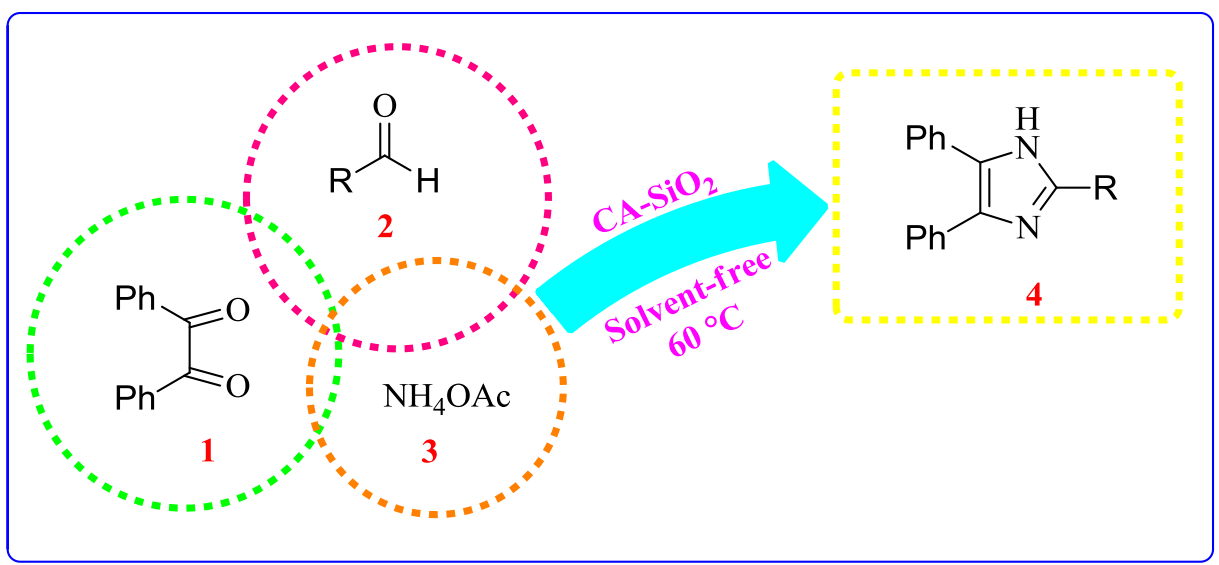

*Corresponding author's E-mail address: nkchemist@yahoo.com

Department of Chemistry, School of Sciences, Alzahra University, Vanak, Tehran, Iran 


\section{Introduction}

There is an increasing interest in the use of environmentally feasible reagents particularly in solvent-free condition. Prevention of organic solvents during reactions in organic synthesis leads to a clean, efficient, and economical technology; not only with the increment of safety, the simplicity of work up, and the reduction of cost, but also by the increased amount of reactants it can be achieved in the same equipment without huge modifications. Reactivity and sometimes selectivity may be enhanced without dilution [1].

Multi-component reactions (MCR) are useful and efficient methods in organic synthesis. The major advantages of these reactions are (1) a single purification step, (2) higher yields than stepwise assembly, (3) the use of simple and diverse precursors to construct complex molecules, and (4) the use of only a single promoter or catalyst. Thus, the development of new multicomponent reaction is a popular area of research in current organic chemistry and is also acceptable from a Green Chemistry point of view [2].

Multi-substituted imidazoles are an important class of compounds in the field of pharmaceuticals and exhibit a wide spectrum of biological activities [3]. Optimization of benzimidazole-based structures has resulted in marketed medicines such as Omeprazole [4], led compounds in a wide range of therapeutic(hepatitis C virus) [5] and eprosartan is one of the series of 1(carboxybenzyl) imdazole-5-acrylic acids, which is a potent and selective angiotensin II receptor antagonist [6]. In addition, many of ionic liquids have imidazole structures [7].

Many methods for the synthesis of this important heterocycle have been published such as four-component condensation of arylglyoxals, primary amines, carboxylic acids and isocyanides on Wang resin [8], hetero-Cope rearrangement [9]. The synthesis of 2,4,5-triaryl-imidazoles from aryl aldehydes and 1,2-diketones or $\alpha$ hydroxy ketone and $\mathrm{NH}_{4} \mathrm{OAc}$ in the presence of ionic liquid [10], silica sulfuric acid [11], $\mathrm{NiCl}_{2} .6 \mathrm{H}_{2} \mathrm{O}$ [12], sodium bisulfite [13], potassium aluminum sulfate (alum) [14], boric acid [15], ceric ammonium nitrate [16], Ionic Liquid [17], L-Proline [18]. Several micro-wave (MW) assisted syntheses of imidazoles in the presence of a variety of catalysts [19-21] have been described. Recently, the use of Caro's acidsilica gel $\left(\mathrm{CA}-\mathrm{SiO}_{2}\right)$ as catalysts or promoters in organic synthesis has attracted great interest from many chemists. $\mathrm{CA}-\mathrm{SiO}_{2}$ can enhance the reactivity and selectivity of many types of reaction, such as oxidative 
coupling of thiols to disulfides [22], synthesis xanthen [23] and synthesis tetrahydrobenzo $[b]$ pyran [24].

\section{Experimental}

\section{Matherials and Methods}

Melting points were taken using the capillary tube technique with an electrothermal 9200 apparatus and are uncorrected. IR spectra were recorded from KBr disk on the FT-IR Bruker Tensor 27. 1H NMR spectra were recorded on a Bruker AQS Avance 500-MHz spectrometer by using tetramethylsilane (TMS) as an internal standard. All the reagents and solvents were purchased from Merck and Aldrich with high-grade quality and without any purification was used.

\section{General Procedure}

A mixture of aromatic aldeyde (1 mmol), benzyl (1 mmol) and ammonium acetate (1.2 mmol) and of Caro's acid (0.1 g) was magnetically stirred at $60{ }^{\circ} \mathrm{C}$ for the appropriate time as indicated in Table 3. The reaction was followed by TLC. After completion, the reaction mixture was washed with $\mathrm{CHCl}_{3}$. For further purification it was crystallized with ethanol to afford the pure product.

\section{Selected spectroscopic data}

\section{2-(4,5-Diphenyl-1H-imidazol-2-yl)-phenol} (4a) mp: $273-275^{\circ} \mathrm{C}$; IR: $1262,1501,1583,1601$, 3058, 3204, $3409 \mathrm{~cm}^{-1} ; \quad{ }^{1} \mathrm{H} \quad \mathrm{NMR}$ (CDCl $3 /$ DMSO-d6, $500 \mathrm{MHz}) \delta$ 6.90-7.02 (d, $2 \mathrm{H}, J=7.5 \mathrm{~Hz}$ ), 7.26-7.64 (m, 10H), 7.95- 7.98 (d, 2H., J=8.06 Hz), 9.08 (s, 1H), 12.74 ppm (brs, 1H).

2-(4-Methyl-phenyl)-4,5-diphenyl-1Himidazole (4c)

mp 225-227 ${ }^{\circ} \mathrm{C}$; IR: $1250,1528,1613$, 2958, $3407 \mathrm{~cm}^{-1}$; ${ }^{1} \mathrm{H}$ NMR: $\delta \mathrm{CDCl}_{3} / \mathrm{DMSO}-\mathrm{d} 6$, $500 \mathrm{MHz}) \delta 3.09\left(\mathrm{~s}, 3 \mathrm{H}, \mathrm{CH}_{3}\right), 7.03-7.83(\mathrm{~m}$, $12 \mathrm{H}), 8.02-8.052(\mathrm{~d}, 2 \mathrm{H}, J=8.3 \mathrm{~Hz}), 12.60$ ppm (brs, NH).

\section{Results and Discussion}

In connection with our ongoing work on synthesis of heterocyclic compounds with $\mathrm{CA}-\mathrm{SiO}_{2}[25,26]$ wish to report a facile procedure for preparation of imidazoles derivatives with $\mathrm{CA}-\mathrm{SiO}_{2}$ as a nontoxic, inexpensive, and easily available reagent. In our initial research, aromatic aldehyde was selected as the representative aldehydes to examine the catalytic activity of different acids. In a general experimental procedure, a mixture of aromatic aldehydes (1 mmol), benzyl (1 mmol) and ammonium acetate (1.2 mmol) was magnetically stirred at $60{ }^{\circ} \mathrm{C}$ in the presence of various catalysts (0.02 mol\%).

Then the reaction mixture was washed with $\mathrm{H}_{2} \mathrm{O}$. The pure product was obtained by recrystallization using acetone. As a result, 
we can conclude from Table 1 that all acids, examined were very effective and all the reactions were completed within 20-60 min. in excellent yields.

Table1. Catalytic activity of various catalysts for the reaction of benzyl, benzaldehyde and $\mathrm{NH}_{4} \mathrm{OAc}$

\begin{tabular}{cccc}
\hline Entry & Catalyst & $\begin{array}{c}\text { Time } \\
\text { (min) }\end{array}$ & $\begin{array}{c}\text { Yield } \\
(\mathbf{\%})^{\mathbf{a}}\end{array}$ \\
\hline 1 & MCM & 30 & 89 \\
2 & Cellulose- & 60 & 83 \\
& $\mathrm{OSO}_{3} \mathrm{H}$ & & \\
3 & $\mathrm{NH}_{2} \mathrm{SO}_{3} \mathrm{H}$ & 25 & 90 \\
4 & $\mathrm{CA}-\mathrm{SiO}_{2}$ & 15 & 93 \\
\hline${ }^{a}$ Isolated yields & &
\end{tabular}

Considering the reaction times and the yields, Caro's acid was selected as the optimum catalyst used in the following study. To evaluate the effect of catalyst concentration, the model reaction was carried out in the presence of different amounts of catalyst (Table 2).

Table 2. Optimization amount of $\mathrm{CA}-\mathrm{SiO}_{2}$ on the reaction of benzyl, benzaldehyde and $\mathrm{NH}_{4} \mathrm{OAc}$

\begin{tabular}{cccc}
\hline Entry & $\begin{array}{c}\text { Catalyst } \\
\text { (g) }\end{array}$ & $\begin{array}{c}\text { Time } \\
\text { (min) }\end{array}$ & $\begin{array}{c}\text { Yield } \\
(\mathbf{\%})^{\mathbf{a}}\end{array}$ \\
\hline 1 & 0.04 & 35 & 89 \\
2 & 0.08 & 20 & 90 \\
3 & 0.1 & 15 & 93 \\
\hline
\end{tabular}

The results showed that $0.1 \mathrm{~g}$ of catalyst was sufficient to achieve a fairly high yield. With $0.04 \mathrm{~g}$ of Caro's acid, a lower yield was observed under the same reaction period. Encouraged by these results, we extended this study using various aromatic aldehydes in the presence of a catalytic amount of acid. The results are summarized in Table 3.

We found that several aromatic aldehydes carrying either electron-releasing or electron-withdrawing substitutes in the meta, and para positions the products the reaction proceeded very efficiently in all cases but for electron withdrawing substitutes longer reaction times need to drive the reaction to completion.

In order to show the merit of Caro's acid in comparison with other reported catalysts, we summarized some of the results for the preparation of 2,4,5-triaryl-imidazoles in Table 4, which shows that Caro's acid is more efficient catalyst with respect to reaction time and yield than previously reported ones.

Table 3. Synthesis of compound 4a-g by Caro's acid

\begin{tabular}{|c|c|c|c|c|c|}
\hline Entry & Product $^{\mathbf{a}}$ & $\mathbf{R}$ & Time (min) & Yield (\%) ${ }^{\mathbf{b}}$ & $\operatorname{Mp}\left({ }^{\circ} \mathrm{C}\right)$ [Lit $]$ \\
\hline 1 & $4 \mathrm{a}$ & $\overline{\mathrm{C}_{6} \mathrm{H}_{5}}$ & 15 & 93 & $273-275[272-273]^{12}$ \\
\hline 2 & $4 \mathrm{~b}$ & $4-\mathrm{HO}_{-} \mathrm{C}_{6} \mathrm{H}_{4}$ & 22 & 90 & $230-233[230-232]^{14}$ \\
\hline 3 & $4 c$ & $4-\mathrm{Me}-\mathrm{C}_{6} \mathrm{H}_{4}$ & 15 & 92 & $225-227[229-231]^{12}$ \\
\hline 4 & $4 d$ & $4-\mathrm{OMe}-\mathrm{C}_{6} \mathrm{H}_{4}$ & 20 & 91 & $231-234[230-232]^{27}$ \\
\hline 5 & $4 \mathrm{e}$ & $4-\mathrm{NO}_{2}-\mathrm{C}_{6} \mathrm{H}_{4}$ & 30 & 87 & $230-232[235-238]^{12}$ \\
\hline 6 & $4 \mathrm{f}$ & $4-\mathrm{Cl}-\mathrm{C}_{6} \mathrm{H}_{4}$ & 25 & 91 & $263-266[262-264]^{27}$ \\
\hline 7 & $4 g$ & 3- $\mathrm{NO}_{2}-\mathrm{C}_{6} \mathrm{H}_{4}$ & 30 & 89 & $312-315[313-315]^{12}$ \\
\hline
\end{tabular}


Table 4. Comparison of Caro's acid with reported catalysts in synthesis $4 \mathbf{a}$

\begin{tabular}{ccccc}
\hline Catalyst/solvent/temperature $/{ }^{\circ} \mathbf{C}$ & Catalyst load & Time (min.) & Yield (\%) & Ref. \\
\hline $\mathrm{KAl}\left(\mathrm{SO}_{4}\right) .12 \mathrm{H}_{2} \mathrm{O} /$ ethanol/ 70 & $0.3 \mathrm{~g}$ & 150 & 93 & {$[14]$} \\
$\mathrm{CAN} /$ ethanol-water/ 65 & 10 mole $\%$ & 50 & 98 & {$[16]$} \\
$\mathrm{BO}_{3} \mathrm{H}_{3} /$ ethanol-water/ r.t. & 5 mole $\%$ & 30 & 98 & {$[15]$} \\
Sodium bisulfite/ ethanol-water/ 80 & 10 mole $\%$ & 30 & 98 & {$[13]$} \\
Caro's acid /Solvent-free/ 60 & $0.1 \mathrm{~g}$ & 15 & 93 & This work \\
\hline
\end{tabular}

\section{Conclusion}

In conclusion, we developed an efficient and simple alternative for the preparation of 2,4,5-triaryl-imidazoles via Caro's acid catalyzed under Solvent-free conditions. Prominent among the advantages of this new method are operational simplicity, good yields, short times and an easy work-up procedure.

\section{Acknowledgements}

We are grateful to Alzahra University Research Council for partial support of this work.

\section{References}

[1]. K. Tanaka, F. Toda, Chem. Rev., 2002, 102, 2751.

[2]. A. Dcmling, Ugi, I. Angew. Chem., 2000, $112,3300$.

[3]. J.G. Lombardino, E.H. Wiseman, J. Med. Chem., 1974, 17, 1182-1188.

[4]. P. Lindberg, P. Nordberg, T. Alminger, A. Brandstorm, B. Wallmark, J. Med. Chem., 1989, 29, 1327-1329.

[5]. P.L. Beaulieu, Y. Bousquet. J. Gauthier, J.
Gillard, M. Marquis, G. McKercher, C. Pellerin, S. Valois, G. Kukoli, J. Med. Chem., 2004, 47, 6884-6892.

[6]. M.E. Pierce, D.Y. Carini, G. Huhn, G.Y. Wells, J.F. Arnett, J. Org. Chem., 1993, 58, 4642-4645.

[7]. T. Welton, Chem. Rev., 1999, 99, 20712084.

[8] C. Zhang, E.J. Moran, T.F. Woiwade, K.M. Short, A.M.M. Mjalli, Tetrahedron Lett., 1996, 37, 751-754.

[9]. I. Lantos, W.Y. Zhang, X. Shiu, D.S. Eggleston, J. Org. Chem., 1993, 58, 70927095.

[10]. S.A. Siddiquo, U.C. Narkhede, S.S. Palmikar, T. Daniel, R.J. Lahoti, K.V. Srinivasan, Tetrahedron, 2005, 61, 35393546.

[11]. A. Shaabani, A. Rahmati, J. Mol. Catal. A Chem., 2006, 249, 246-248.

[12]. M.M. Heravi, K. Bakhtiari, H.A. Oskooie, S. Taheri, J. Mol. Catal. A Chem., 2007, 263 279-281.

[13]. J.N. Sangshetti, N.D. Kokare, S.A. 
Kotharkar, D.B. Shinde, Monatsh. Chem., 2008, 139 125-127.

[14]. A.A. Mohammadi, M. Mivechi, H. Kefayati, Monatsh. Chem., 2008, 139, 935.

[15]. K.F. Shelke, S.B. Sapkal, S.S. Sonar, B.R.

Madje, B.B. Shingate, S. Shingare, Bull Korean Chem. Soc., 2009, 30, 1057.

[16]. J.N. Sangshetti, N.D. Kokare, S.A. Kotharkara, D.B. Shinde, J. Chem. Sci., 2008, 120, 463-467.

[17]. M.M. Heravi, M. Zakeri, N. Karimi, M. Saeedi, H.A. Oskooie, Synth. Commun., 2009, 40, 1998.

[18]. S. Samai, G.C. Nandi, P. Singh, M.S. Singh, Tetrahedron, 2009, 65, 10155-10161. [19]. S. Balalaie, M.M. Hashemi, M. Akhbari, Tetrahedron Lett., 2003, 44, 1709-1711.

[20]. S. Balalaie, A. Arabanian, Green. Chem., 2000, 2, 274-276.
[21]. A.Y. Usyatinsky, Y. L. Khemelnitsky, Tetrahedron Lett., 2000, 41, 5031-5034.

[22]. B. Movassagh, M.M. Lakouraj, K. Ghodrati, Synth. Commun., 1999, 29, 35973603.

[23]. H.A. Oskooie, M.M. Heravi, N. Karimi, L. Tahershamsi, Synth.Commun., 2011, 41, 307-312.

[24]. H.A. Oskooie, M.M. Heravi, N. Karimi, M. Ebrahimzadeh, Synth.Commun., 2011, 41, 436-440.

[25]. H.A. Oskooie, M.M. Heravi, N. Karimi, G. Kohansal, Synth.Commun., 2011, 41, 27632768.

[26]. M.M. Heravi, H. Hamidi, N. Karimi, A. Amouchi, Adv. J. Chem. A, 2018, 1, 1-6.

[27]. D.M. White, J. Sonnenberg, J. Org. Chem., 1964, 29, 1926-1930.

How to cite this manuscript: Majid M. Heravi, Narges Karimi*, Samira Pooremami, OnePot Three Components Synthesis of 2,4,5-Triaryl-Imidazoles Catalyzed by Caro's AcidSilica Gel Under Solvent-Free Condition, Adv. J. Chem. A, 2019, 2(1), 73-78. 